\title{
Younger patients with chronic myeloid leukemia do well in spite of poor prognostic indicators: results from the randomized CML study IV
}

\author{
Lida Kalmanti • Susanne Saussele • Michael Lauseker • Ulrike Proetel • Martin C. Müller • \\ Benjamin Hanfstein • Annette Schreiber • Alice Fabarius • Markus Pfirrmann • Susanne Schnittger • \\ Jolanta Dengler • Christiane Falge • Lothar Kanz • Andreas Neubauer • Frank Stegelmann • \\ Michael Pfreundschuh • Cornelius F. Waller • Karsten Spiekermann • Stefan W. Krause • \\ Dominik Heim • Christoph Nerl • Dieter K. Hossfeld • Hans-Jochem Kolb • Andreas Hochhaus • \\ Joerg Hasford • Rüdiger HehImann • German Chronic Myeloid Leukemia Study Group • \\ Schweizerische Arbeitsgemeinschaft für Klinische Krebsforschung (SAKK)
}

Received: 25 July 2013 / Accepted: 9 October 2013 / Published online: 27 October 2013

(C) The Author(s) 2013. This article is published with open access at Springerlink.com

\begin{abstract}
Since the advent of tyrosine kinase inhibitors, the impact of age on outcome of chronic myeloid leukemia (CML) patients has changed. We therefore analyzed patients from the randomized CML study IV to investigate disease
\end{abstract}

Data presented in part at the ELN Frontiers Meeting, November 9-11, 2012, Istanbul, Turkey

The study is registered at NIH, ClinicalTrials.gov identifier: NCT00055874 (http://clinicaltrials.gov)

Electronic supplementary material The online version of this article (doi:10.1007/s00277-013-1937-4) contains supplementary material, which is available to authorized users.

L. Kalmanti · S. Saussele $(\bowtie) \cdot$ U. Proetel · M. C. Müller •

B. Hanfstein · A. Schreiber · A. Fabarius · R. Hehlmann

III. Medizinische Klinik, Universitätsmedizin Mannheim,

Pettenkoferstrasse 22, 68169 Mannheim, Germany

e-mail: susanne.saussele@medma.uni-heidelberg.de

M. Lauseker · M. Pfirmann · J. Hasford

Institut für Medizinische Informationsverarbeitung, Biometrie und

Epidemiologie (IBE), Ludwig-Maximilians-Universität München,

Munich, Germany

S. Schnittger

MLL-Münchner Leukämielabor GmbH, Munich, Germany

J. Dengler

Abteilung Innere Medizin V, Medizinische Klinik,

Universitätsklinikum Heidelberg, Heidelberg, Germany

C. Falge

Medizinische Klinik 5, Klinikum Nürnberg Nord, Nürnberg,

Germany manifestations and outcome in different age groups. One thousand five hundred twenty-four patients with BCR-ABLpositive chronic phase CML were divided into four age groups: (1) 16-29 years, $n=120$; (2) $30-44$ years, $n=383$;
L. Kanz

Medizinische Klinik, Abteilung II, Universitätsklinikum Tübingen, Tübingen, Germany

\section{A. Neubauer}

Klinik für Innere Medizin, Schwerpunkt Hämatologie, Onkologie und Immunologie, Universitätsklinikum Marburg, Marburg, Germany

F. Stegelmann

Klinik für Innere Medizin III, Universitätsklinikum Ulm, Ulm, Germany

M. Pfreundschuh

Klinik für Innere Medizin I, Universitätsklinikum des Saarlandes, Homburg/Saar, Germany

C. F. Waller

Klinik für Innere Medizin I, Universitätsklinikum Freiburg, Freiburg, Germany 
(3) 45-59 years, $n=495$; and (4) $\geq 60$ years, $n=526$. Group 1 (adolescents and young adults (AYAs)) presented with more aggressive disease features (larger spleen size, more frequent symptoms of organomegaly, higher white blood count, higher percentage of peripheral blasts and lower hemoglobin levels) than the other age groups. In addition, a higher rate of patients with BCR-ABL transcript levels $>10 \%$ on the international scale (IS) at 3 months was observed. After a median observation time of 67.5 months, no inferior survival and no differences in cytogenetic and molecular remissions or progression rates were observed. We conclude that AYAs show more aggressive features and poor prognostic indicators possibly indicating differences in disease biology. This, however, does not affect outcome.

Keywords Chronic myeloid leukemia $\cdot$ Accelerated phase . Blast crisis · Young adults and adolescents

\section{Introduction}

Chronic myeloid leukemia (CML) appears in all age groups. The incidence increases with age. In western countries, median age at diagnosis is 64 years $[1,2]$ and around 54 years [3] in clinical studies. Before the introduction of imatinib, older age was a negative prognostic factor, as reflected by the risk stratification scores, Sokal and Euro [4, 5]. After the introduction of imatinib, the outcome of patients with CML has improved, and older age seems to have lost its negative impact [6, 7].

\section{K. Spiekermann \\ Medizinische Klinik und Poliklinik III, Klinikum der Ludwig \\ Maximilians-Universität, Munich, Germany \\ S. W. Krause \\ Medizinische Klinik 5, Universitätsklinikum Erlangen, Erlangen, Germany \\ D. Heim \\ Klinik für Hämatologie, Universitätsspital, Basel, Switzerland \\ C. Nerl \\ Klinik für Hämatologie, Onkologie, Immunologie, Palliativmedizin, Infektiologie und Tropenmedizin, Klinik Schwabing, Munich, Germany \\ D. K. Hossfeld \\ II. Medizinische Klinik, Universitätsklinikum Eppendorf, Hamburg, Germany}

\section{H.-J. Kolb}

Klinikum rechts der Isar, Technische Universität München, Munich, Germany

\section{A. Hochhaus}

Abteilung Hämatologie/Onkologie, Universitätsklinikum Jena, Jena, Germany
A recent analysis that compares patients less than 65 years with patients older than 65 years treated with frontline imatinib reports no difference in an outcome between these two age groups [8]. Another analysis that compares 15-29year-old adolescents and young adults (AYAs) with patients older than 29 years with newly diagnosed chronic phase (CP) CML treated with first-line tyrosine kinase inhibitors (TKIs) reports inferior response rates in the younger group [9]. AYAs have been of particular interest in oncology because differences compared to older age have been observed in various neoplasias: In acute lymphoblastic leukemia, different disease features and a better outcome are reported in AYAs in comparison to older patients $[10,11]$. A worse prognosis has been reported in breast cancer [12,13], colorectal cancer [14], and soft tissue sarcomas [15], pointing to different biological features of these cancers in younger age [16].

Few data exist on presentation and outcome of AYAs with CML possibly due to the low incidence of CML in this age group.

The aim of this study was to analyze the impact of age on outcome of CML using patients from the German CML study IV with particular attention to the group of patients younger than 29 years.

\section{Patients and methods}

The German CML study IV is a five-arm randomized study which compares $400 \mathrm{mg}$ imatinib, $800 \mathrm{mg}$ imatinib, $400 \mathrm{mg}$ imatinib in combination with interferon alpha (IFN- $\alpha$ ), $400 \mathrm{mg}$ imatinib in combination with low-dose cytarabine, and $400 \mathrm{mg}$ imatinib after failure to IFN- $\alpha$ [17].

Newly diagnosed BCR-ABL-positive CP-CML patients diagnosed in participating centers were included. There was no upper age limit. Patients with comorbidities that would preclude study participation or study drug treatment were excluded as well as pregnant or nursing women and patients with secondary malignancy causing reduced life expectancy or requiring therapy.

Patients, 16 years and older, were included. Twenty-nine years was defined as upper cutoff age for AYAs [9, 18-21]. For older patients, the lower cut off at age 60 years was chosen [6, 22]. Age groups, 30-59, were evenly divided into two groups (30-44 and 45-59).

Gender, performance status, risk scores, clinical manifestations, blood count, type of transcripts, and presence of additional chromosomal aberrations (ACAs) [23] were analyzed at the time of diagnosis. Cytogenetic and molecular responses, rates of progression to accelerated phase (AP) and blast crisis (BC), and overall survival (OS) were analyzed throughout the observation time of the study. Patients were analyzed for achieving complete cytogenetic remission (CCR), major molecular remission (MMR), and molecular 
Fig. 1 Overview of evaluable patients according to age groups. $n$ Number of patients, $C M L$ chronic myeloid leukemia, $C P$ chronic phase, $O S$ overall survival, $C C R$ complete cytogenetic remission, $M M R$ major molecular remission, $M R^{4}$ molecular remission $\leq 0.01 \%$ on the international scale

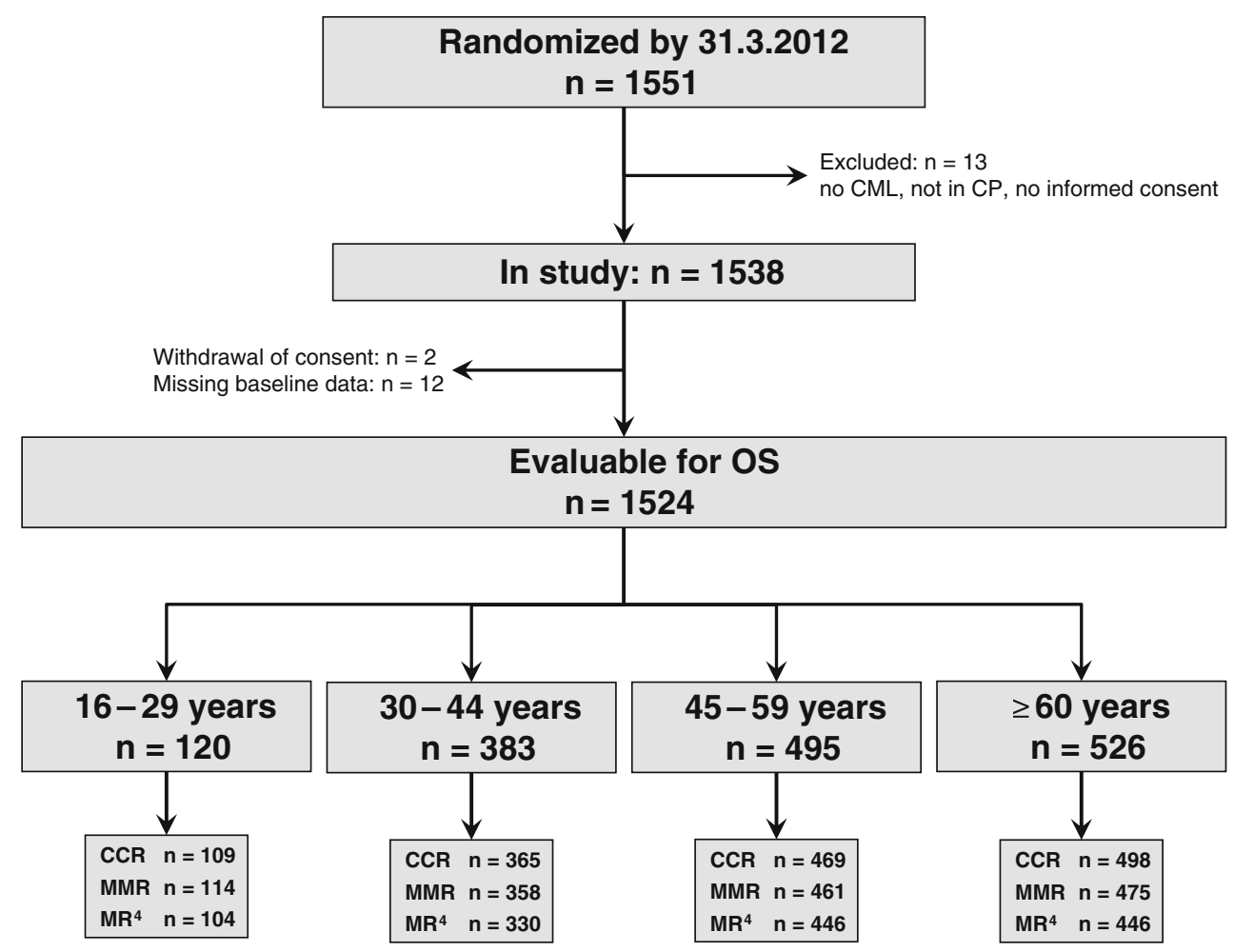

remission $\leq 0.01 \%$ on the international scale $\left(\mathrm{MR}^{4}\right)$, if at least one sample of sufficient quality was available.

For follow-up analyses of CCR, at least 20 marrow cell metaphases were evaluated. Measurements of BCR-ABL and total ABL transcripts were determined by quantitative reverse transcriptase polymerase chain reactions from peripheral blood samples [24-26] and were performed in standardized laboratories [27]. The analysis of molecular endpoints was restricted to patients expressing $\mathrm{b} 2 \mathrm{a} 2$ and/or b3a 2 transcripts only.

Response definitions, AP, and BC were defined according to ELN criteria and the recent standardized definitions of molecular response [28-30]. All living patients were censored at the time of their last visit. In estimating the cumulative incidences of molecular or cytogenetic remissions, patients were censored at the time they received a second-generation TKI or were transplanted.
OS was calculated from date of diagnosis to death from any cause (whether on or off TKI) or to the latest follow-up date.

Baseline characteristics and hematological parameters were compared with the chi-squared or the Kruskal-Wallis tests. Cumulative incidences were calculated under consideration of competing risks [31, 32] defined by AP, BC, and death. Probabilities of OS were calculated by the Kaplan-Meier method and compared by log-rank test. Comparisons between cumulative incidences were performed by the Gray test [33]. Relative overall survival was calculated dividing the observed survival probabilities by the expected survival probability of the general German population matching age and sex. Level of significance was 0.05 . Due to the exploratory character of this work, no adjustment of $p$ values was done. All calculations were performed with the SAS software Version 9.1.3.

The protocol followed the Declaration of Helsinki and was approved by the ethics committee of the Medizinische
Table 1 Patients and treatment arms

$N$ number of patients, $I F N-\alpha$ interferon

\begin{tabular}{lcccc}
\hline Age groups, years & $16-29$ & $30-44$ & $45-59$ & At least 60 \\
\hline All patients, $n$ & 120 & 383 & 495 & 526 \\
$\quad$ Imatinib (400 mg), $n(\%)$ & $25(21)$ & $93(24)$ & $131(26)$ & $147(28)$ \\
Imatinib (400 mg + IFN- $\alpha), n(\%)$ & $39(32)$ & $102(27)$ & $139(28)$ & $145(27)$ \\
Imatinib (400 mg + cytarabine), $n(\%)$ & $13(11)$ & $39(10)$ & $53(11)$ & $53(10)$ \\
Imatinib (400 mg after IFN- $\alpha$ failure), $n(\%)$ & $8(7)$ & $35(9)$ & $37(7)$ & $48(9)$ \\
Imatinib (800 mg), $n(\%)$ & $35(29)$ & $114(29)$ & $135(27)$ & $133(25)$ \\
\hline
\end{tabular}


Table 2 Patient's characteristics

\begin{tabular}{|c|c|c|c|c|}
\hline Age groups, years & $16-29$ & $30-44$ & $45-59$ & At least 60 \\
\hline Number of patients, $n(\%)$ & $120(8)$ & $383(25)$ & $495(32)$ & $526(35)$ \\
\hline Male & $80(67)$ & $255(67)$ & $301(61)$ & $283(54)$ \\
\hline Female & $40(33)$ & $128(33)$ & 194 (39) & $243(46)$ \\
\hline$p$ & & & & $0.011^{\mathrm{a}}$ \\
\hline \multicolumn{5}{|l|}{ Karnofsky index, $n(\%)$} \\
\hline $50-80$ & $13(12)$ & $31(9)$ & $42(9)$ & $74(16)$ \\
\hline$>80-<100$ & $32(29)$ & $86(25)$ & $144(32)$ & $166(35)$ \\
\hline 100 & $65(59)$ & $226(66)$ & $271(59)$ & $234(49)$ \\
\hline$p$ & & $<0.001^{\mathrm{a}}$ & $<0.001^{\mathrm{a}}$ & $<0.001^{\mathrm{a}}$ \\
\hline Missing & 10 & 40 & 38 & 52 \\
\hline \multicolumn{5}{|l|}{ EUTOS score, $n(\%)$} \\
\hline Low & $97(82)$ & $320(84)$ & $436(89)$ & $473(92)$ \\
\hline High & $22(18)$ & $63(16)$ & $54(11)$ & $41(8)$ \\
\hline$p$ & & & $0.031^{\mathrm{a}}$ & $0.002^{\mathrm{a}}$ \\
\hline Missing & 1 & 0 & 5 & 12 \\
\hline \multicolumn{5}{|l|}{ Sokal score ${ }^{\mathrm{b}}, n(\%)$} \\
\hline Low & $64(54)$ & $190(50)$ & $226(46)$ & $90(17)$ \\
\hline Intermediate & $23(19)$ & $100(26)$ & $155(32)$ & $300(58)$ \\
\hline High & $31(26)$ & $92(24)$ & $110(22)$ & $125(24)$ \\
\hline$p$ & & & $0.035^{\mathrm{a}}$ & $<0.001^{\mathrm{a}}$ \\
\hline Missing & 2 & 1 & 4 & 11 \\
\hline \multicolumn{5}{|l|}{ Euro score $^{\mathrm{b}}, n(\%)$} \\
\hline Low & $70(59)$ & $267(70)$ & $144(29)$ & $69(13)$ \\
\hline Intermediate & $29(24)$ & $84(22)$ & $286(58)$ & $391(75)$ \\
\hline High & $20(17)$ & $31(8)$ & $65(13)$ & $61(12)$ \\
\hline$p$ & & $0.013^{\mathrm{a}}$ & $<0.001^{\mathrm{a}}$ & $<0.001^{\mathrm{a}}$ \\
\hline Missing & 1 & 1 & 0 & 5 \\
\hline Presence of organomegaly-related symptoms, $n(\%)$ & $33(29)$ & $86(24)$ & $84(18)$ & $37(7)$ \\
\hline$p$ & & & $0.009^{\mathrm{a}}$ & $<0.001^{\mathrm{a}}$ \\
\hline Missing & 5 & 19 & 18 & 23 \\
\hline \multicolumn{5}{|l|}{ Spleen size, below costal margin } \\
\hline Median (range), $\mathrm{cm}$ & $5(0-38)$ & $3(0-28)$ & $1(0-25)$ & $0(0-23)$ \\
\hline$p$ & & $0.014^{\mathrm{a}}$ & $<0.001^{\mathrm{a}}$ & $<0.001^{\mathrm{a}}$ \\
\hline Missing, $n$ & 1 & 0 & 2 & 6 \\
\hline \multicolumn{5}{|l|}{ Blasts in blood } \\
\hline Median (range), $\%$ & $2(0-19)^{\mathrm{c}}$ & $1(0-17)^{\mathrm{c}}$ & $1(0-30)^{\mathrm{c}}$ & $0(0-15)$ \\
\hline$p$ & & & $0.010^{\mathrm{a}}$ & $<0.001^{\mathrm{a}}$ \\
\hline Missing, $n$ & 1 & 1 & 4 & 6 \\
\hline \multicolumn{5}{|l|}{ WBC } \\
\hline Median (range), $10^{9} / \mathrm{L}$ & $144(9-571)$ & $106(3-539)$ & $74(3-630)$ & $57(3-582)$ \\
\hline$p$ & & $0.044^{\mathrm{a}}$ & $<0.001^{\mathrm{a}}$ & $<0.001^{\mathrm{a}}$ \\
\hline Missing, $n$ & 1 & 2 & 2 & 3 \\
\hline \multicolumn{5}{|l|}{ Hemoglobin } \\
\hline Median (range), g/dL & $11.1(6.9-16.2)$ & $11.8(5.2-17.5)$ & $12.6(4.9-19.1)$ & $12.5(4.7-17.6)$ \\
\hline$p$ & & $0.041^{\mathrm{a}}$ & $<0.001^{\mathrm{a}}$ & $<0.001^{\mathrm{a}}$ \\
\hline Missing, $n$ & 2 & 3 & 3 & 5 \\
\hline \multicolumn{5}{|l|}{ Eosinophils } \\
\hline Median (range), (\%) & $2.5(0-12)$ & $2(0-13)$ & $2(0-14)$ & $2(0-28)$ \\
\hline Missing, $n$ & 0 & 2 & 4 & 3 \\
\hline
\end{tabular}


Table 2 (continued)

\begin{tabular}{|c|c|c|c|c|}
\hline Age groups, years & $16-29$ & $30-44$ & $45-59$ & At least 60 \\
\hline \multicolumn{5}{|l|}{ Basophils } \\
\hline Median (range), (\%) & $3(0-19)$ & $3(0-22)$ & $4(0-26)$ & $3(0-66)$ \\
\hline Missing, $n$ & 0 & 2 & 5 & 6 \\
\hline \multicolumn{5}{|l|}{ Platelets } \\
\hline Median (range),$\times 10^{9} / \mathrm{L}$ & $430(59-2,590)$ & $369(39-2,799)$ & $364(49-3,020)$ & $381(34-2,716)$ \\
\hline Missing, $n$ & 0 & 1 & 1 & 2 \\
\hline \multicolumn{5}{|c|}{ BCR-ABL transcript type, $n(\%)$} \\
\hline $\mathrm{b} 2 \mathrm{a} 2$ & $55(48)$ & $146(39)$ & $200(42)$ & $186(38)$ \\
\hline $\mathrm{b} 3 \mathrm{a} 2$ & $42(36)$ & $166(45)$ & $210(44)$ & $233(47)$ \\
\hline Either & $18(16)$ & $61(16)$ & $65(14)$ & $72(15)$ \\
\hline Missing & 5 & 10 & 20 & 35 \\
\hline \multicolumn{5}{|l|}{ ACAs, $n(\%)$} \\
\hline Yes & $6(6)$ & $13(4)$ & $22(5)$ & $12(3)$ \\
\hline No & $98(94)$ & $321(96)$ & $421(95)$ & $452(97)$ \\
\hline Missing & 16 & 49 & 52 & 62 \\
\hline \multicolumn{5}{|c|}{$>10 \%$ BCR-ABL ${ }^{\text {IS }}$ at 3 months } \\
\hline$n,(\%)$ & $25(42)$ & $74(42)$ & $60(26)$ & $53(25)$ \\
\hline$p$ & & & $0.026^{\mathrm{a}}$ & $0.018^{\mathrm{a}}$ \\
\hline Missing, $n$ & 60 & 204 & 263 & 313 \\
\hline \multicolumn{5}{|c|}{$>10 \%$ BCR-ABL ${ }^{\text {IS }}$ at 6 months } \\
\hline$n,(\%)$ & $6(13)$ & $30(19)$ & $28(13)$ & $29(15)$ \\
\hline Missing, $n$ & 72 & 224 & 272 & 320 \\
\hline
\end{tabular}

BCR-ABL ${ }^{\text {IS }}$ BCR-ABL transcript levels on international scale ACAs: additional cytogenetic aberrations except $-Y$

${ }^{\mathrm{a}} p$ value refers to test between group 1 and the respective groups. Values not shown were above 0.05

${ }^{\mathrm{b}}$ In Sokal and Euro score age is included for risk stratification

${ }^{\mathrm{c}}$ Eight patients with blasts in blood $>15 \%$ were included as chronic phase patients after judged so by the treating physicians. All had bone marrow blasts $\leq 10 \%$

Fakultät Mannheim der Universität Heidelberg and by local ethics committees of participating centers. Written informed consent was obtained from all patients before they entered the study.

\section{Results}

One thousand five hundred fifty-one patients with newly diagnosed BCR-ABL-positive CML in CP were randomized from July 2002 through March 2012. Data entry was closed on May 24, 2012.

One thousand five hundred twenty-four patients at the age of 16 years and older were evaluable for follow-up (Fig. 1). The median age at diagnosis was 52 years. The median observation time was $67.5(0.1-123.8)$ months.

Patients were divided into four age groups according to age at diagnosis: group 1, 16-29 years $(n=120,8 \%)$; group 2, $30-44$ years $(n=383,25 \%)$; group $3,45-59$ years $(n=495$, $32 \%$ ); and group $4, \geq 60$ years $(n=526,35 \%)$. All patients received imatinib as first or second-line treatment in the study except for ten patients who only received IFN. Recruitment to this arm was terminated in 2005 [17]. More patients in group 1 were transplanted (19\%) compared to 12,7 , and $1 \%$ in groups 2,3 , and 4 , respectively. The number of patients according to age groups and therapy arm are shown in Table 1.

There was a predominance of male gender in all age groups, but group 1 showed a significantly higher percentage of male patients in comparison to group 4 (67\% for groups 1 and 2 each, $61 \%$ for group 3, and $54 \%$ for group 4, $p=0.011$ ).

Most patients had a Karnofsky index $>80 \%$, but $12 \%$ of patients in group 1 had a Karnofsky index between 50-80\% compared to $9 \%$ in groups 2 and 3 and $16 \%$ in group 4 (Table 2).

Patients in group 1 had the highest proportion of high-risk patients according to Euro and EUTOS scores. By EUTOS score, $18 \%$ of patients in group 1 were high risk in comparison to $16 \%(\mathrm{~ns}), 11 \%(p=0.031)$, and $8 \%(p<$ 0.002 ) in groups 2,3 , and 4 , respectively. 
Group 1 presented with a larger spleen size (median length of $5 \mathrm{~cm}$ below the costal margin), more often with symptoms of organomegaly, higher white blood cell counts (WBC), a higher percentage of blasts in the peripheral blood (median of $144 \times 10^{9} / \mathrm{L}$ ), and lower hemoglobin levels (median of 11.1 $\mathrm{g} / \mathrm{dL}$ ). There were no differences in fatigue, weight loss, fever, or other symptoms, in the percentage of eosinophils, basophils, platelets, bone marrow blasts, ACAs, and type of BCR-ABL transcripts at diagnosis between the four groups (Table 2).

No significant differences in cumulative incidences of $\mathrm{CCR}, \mathrm{MMR}$, and $\mathrm{MR}^{4}$ were found between group 1 and the other 3 groups (Fig. 2a-c).

The 5-year OS probability of group 1 was $96.7 \%$, $93.8 \%$ for group 2, $92.5 \%$ for group 3, and $82.9 \%$ for group 4. OS was lower only in group 4 in comparison to the other three age groups $(p<0.001)$ as observed in the general population [34]. The relative survival (RS) when the general German population was taken into account was $96.9 \%$ in group 1, 94.5, 95.1 , and $93.1 \%$ in groups $2-4$, respectively [34].

Regarding progression during the observation time, no differences were observed between the age groups. The cumulative incidences of progression at 5 years were 8.7, 7.3, 5.3, and $6.1 \%$ for groups 1 to 4 , respectively (Fig. 3).

More patients in group 1 had BCR-ABL ${ }^{\mathrm{IS}} \geq 10 \%$ at 3 months ( $42 \%$ ) than patients above 44 years ( $26 \%$ for group $3, p=0.026$ and $25 \%$ for group $4, p=0.018$ ). There was no difference to group 2 (Table 2).

A correlation between a specific cause of death age group and therapy arm was not observed. Causes of death in each group are shown in Table 3.

\section{Discussion}

The median age of the 1,524 CML patients of the CML study IV was 52 years with a male preponderance. AYAs represented $8 \%$ of the study population in agreement with reports of CML incidence in AYAs $[9,35]$.

AYAs in our study presented features of a more aggressive disease, with higher levels of WBC and blasts in the peripheral blood, lower hemoglobin, larger spleen size, and more frequent organomegaly-related symptoms. The larger spleen size is reflected in the EUTOS score in which age is not included as a parameter and is in line with a study of Pemmaraju et al. who report a higher frequency of splenomegaly at diagnosis in 61 AYAs than in 407 older patients [9], and a study of Cortes et al. who report that splenomegaly was more frequent in patients below 60 years than above 60 years [6]. Similar observations have been made in children with CML (increased rates of splenomegaly and
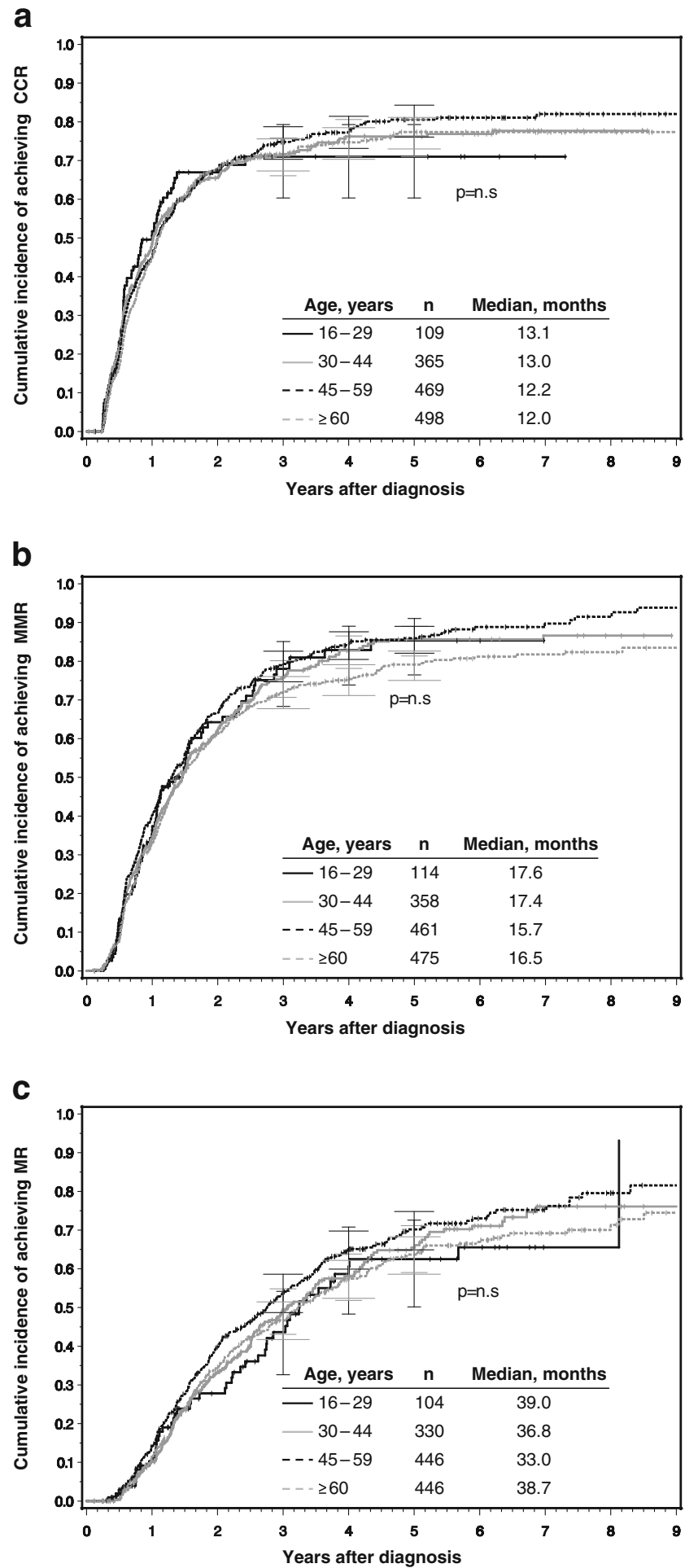

Fig. 2 a-c Cumulative incidences of a CCR, b MMR, and $\mathbf{c} \mathrm{MR}^{4}$ according to the four age groups determined under consideration of competing risks. $n$ Number of patients, $C C R$ complete cytogenetic, remission, $M M R$ major molecular remission, $M R^{4}$ molecular remission $\leq 0.01 \%$ on the international scale. $p$ refers to level of significance between AYAs and the other three age groups

leucocytosis) [36-38], supporting our findings that aggressive disease features become less apparent as age increases. 
Fig. 3 Rates of progression to $\mathrm{AP}$ and $\mathrm{BC}$ according to age group. No statistical difference was observed between the four age groups. $n$ Number of patients, $A P$ accelerated phase, $B C$ blast crisis, $C I$ cumulative incidence. $p$ refers to level of significance between AYAs and the other three age groups

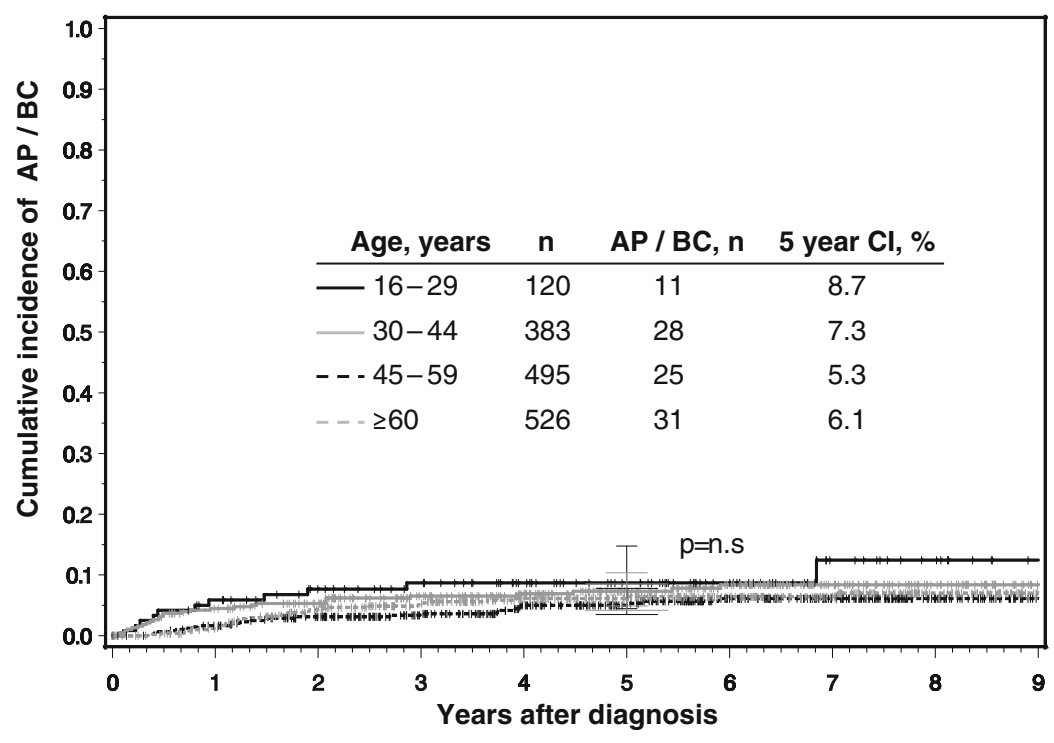

$\begin{array}{lccccccccc}\text { Patients at risk } & \mathbf{1} & \mathbf{2} & \mathbf{3} & \mathbf{4} & \mathbf{5} & \mathbf{6} & \mathbf{7} & \mathbf{8} & \mathbf{9} \\ 16-29 \text { years } & 110 & 99 & 89 & 75 & 60 & 42 & 18 & 11 & 3 \\ 30-44 \text { years } & 354 & 326 & 277 & 240 & 193 & 151 & 91 & 55 & 16 \\ 45-59 \text { years } & 475 & 442 & 376 & 321 & 269 & 200 & 145 & 80 & 33 \\ \geq 60 \text { years } & 490 & 430 & 384 & 315 & 252 & 187 & 136 & 78 & 37\end{array}$

Although a worse outcome was expected in our group of 120 AYAs [9], no differences in cumulative incidence of CCR, $\mathrm{MMR}$, and $\mathrm{MR}^{4}$ were observed in comparison to the other three groups. This is different from the results of Pemmaraju et al. [9] who report significantly lower cytogenetic and molecular responses in AYAs. The two studies however did not find difference in OS. No inferior survival after a median observation time of 5.6 years was observed in our study either. We have observed, however, a greater percentage of younger patients with BCR-ABL transcript levels above $10 \%$ at 3 months in comparison to patients 44 years and older. Transcript levels above $10 \%$ are correlated with an unfavorable prognosis [39, 40] and identify patients that require more frequent monitoring [41].

These findings could suggest different disease biology of CML in younger patients. The identification of distinct agerelated genetic and biologic features has been found in various neoplasms: in colon cancer chromosomal instability and a greater tumor invasion is observed in younger patients [42]. In papillary thyroid cancer, different gene expression and advanced disease presentation in AYAs were correlated with better prognosis [43]. In breast cancer, younger women show unique genetic pathways recognized as negative prognostic markers [13]. In acute lymphoblastic leukemia (ALL), distinct
Table 3 Causes of death

Multiple causes are possible. Autopsy performed only in few cases

$n$ number of patients, $A P$ accelerated phase, $B C$ blast crisis, $C P$ chronic phase, $S C T$ stem cell transplantation

\begin{tabular}{lrrrr}
\hline Age groups, years & $16-29$ & $30-44$ & $45-59$ & At least 60 \\
\hline All patients, $n$ & 120 & 383 & 495 & 526 \\
Total deaths & 4 & 23 & 38 & 87 \\
Progression to AP, BC & 1 & 7 & 13 & 22 \\
SCT related & 2 & 6 & 8 & 1 \\
Infection in CP & 0 & 2 & 2 & 8 \\
Secondary malignancy & 0 & 0 & 2 & 21 \\
Bleeding & 0 & 2 & 1 & 0 \\
Cardiopulmonary & 1 & 0 & 2 & 14 \\
Renal insufficiency & 0 & 0 & 0 & 3 \\
Thromboembolic/ischemic (not cardiac) & 0 & 1 & 2 & 2 \\
Suicide & 0 & 0 & 0 & 2 \\
Others & 0 & 1 & 2 & 4 \\
Unknown & 0 & 4 & 6 & 10 \\
\hline
\end{tabular}


biological findings are reported in AYAs, which are generally correlated with poor prognosis: increased incidence of Philadelphia chromosome and intrachromosomal amplification of chromosome 21 , increased promoter methylation, and more frequent $\mathrm{T}$ cell immunophenotype as well as presence of a mediastinal mass. Due to treatment optimization, ALL outcome is better in AYAs than in adults $[10,11,44]$.

In our analysis, we did not detect obvious biological differences. We did not observe differences in transcript type or ACAs nor did others: no differences in transcript type in relation to age were found in 146 pediatric CML patients, including 30 AYAs [36]. Differences in stem cell biology, bone marrow microenvironment, or signaling pathways could exist since many biologic pathways are triggered by BCRABL and are successfully inhibited by TKI therapy [45-47] but data to support this in AYAs are still lacking.

Another possible interpretation of the more aggressive features at diagnosis of CML in AYAs could be that younger patients are less frequently transferred to the physician than older ones and only when symptoms are apparent as a consequence of better health and less frequent comorbidities than in older people. As there are no data to support this hypothesis, this remains speculative.

Since the introduction of imatinib, response rates have improved and progression of the disease rarely occurs [48]. Treatment with imatinib explains the high 5-year OS of AYAs in our study $(97 \%)$ in comparison to a recently published population-based study in the Netherlands, which started in the pre-imatinib era (1989-2009), in which the 5-year relative survival of AYAs with CML is reported to be $68 \%$ in males and $76 \%$ in females [49].

We conclude that AYAs with CML show features of a more aggressive disease indicating possible biological differences of younger patients that need to be investigated. Also, the higher transcript level at 3 months suggests a worse prognosis of AYAs. Nevertheless, younger patients do well in spite of poorer prognostic indicators.

Acknowledgments The authors would like to thank Gabriele Bartsch, Uwe Böhm, Elke Matzat, Sabine Dean, Ute Kossak, Barbara Müller, Regina Pleil-Lösch, Nicole Schomber, Andrea Poetsch, Inge Stalljann, and all CML trial participants (see supplemental Appendix in the online article).

Conflict of interest The CML study IV is supported by the Deutsche Krebshilfe (no. 106642 and 109588), Novartis, Nürnberg, Germany, Kompetenznetz für Akute and Chronische Leukämien (BMBF 01GI0270), José-Carreras Leukämiestiftung (DJCLS H09/01f, H06/04v, H03/01, R05/23), and the European LeukemiaNet (LSHC-CT-2004503216). The authors declare no conflicts of interest.

Open Access This article is distributed under the terms of the Creative Commons Attribution License which permits any use, distribution, and reproduction in any medium, provided the original author(s) and the source are credited.

\section{References}

1. Howlader N, Noone A, Krapcho M, Neyman N, Aminou R, Altekruse S, Kosary C, Ruhl J, Tatalovich Z, Cho H, Mariotto A, Eisner M, Lewis D, Chen H, Feuer E, Cronin K, (Editors) SEER Cancer Statistics Review, 1975-2009 (Vintage 2009 Populations).Bethesda, MD:National Cancer Institute;2012http:// seer.cancer.gov/csr/1975_2009_pops09/. Accessed 10 March 2012

2. Bjorkholm M, Ohm L, Eloranta S, Derolf A, Hultcrantz M, Sjoberg J, Andersson T, Hoglund M, Richter J, Landgren O, Kristinsson SY, Dickman PW (2011) Success story of targeted therapy in chronic myeloid leukemia: a population-based study of patients diagnosed in Sweden from 1973 to 2008. J Clin Oncol 29(18):2514-2520. doi:10. 1200/jco.2011.34.7146

3. Rohrbacher M, Berger U, Hochhaus A, Metzgeroth G, Adam K, Lahaye T, Saussele S, Müller MC, Hasford J, Heimpel H, Hehlmann $\mathrm{R}$ (2009) Clinical trials underestimate the age of chronic myeloid leukemia (CML) patients. Incidence and median age of $\mathrm{Ph} / \mathrm{BCR}$ ABL-positive CML and other chronic myeloproliferative disorders in a representative area in Germany. Leuk 23(3):602-604. doi:10.1038/ leu.2008.245

4. Sokal JE, Cox EB, Baccarani M, Tura S, Gomez GA, Robertson JE, Tso CY, Braun TJ, Clarkson BD, Cervantes F, Rozman C (1984) Prognostic discrimination in "good-risk" chronic granulocytic leukemia. Blood 63(4):789-799

5. Hasford J, Pfirrmann M, Hehlmann R, Allan NC, Baccarani M, Kluin-Nelemans JC, Alimena G, Steegmann JL, Ansari H (1998) A new prognostic score for survival of patients with chronic myeloid leukemia treated with interferon alfa. Writing Committee for the Collaborative CML Prognostic Factors Project Group. J Natl Cancer Inst 90(11):850-858

6. Cortes J, Talpaz M, O'Brien S, Giles F, Rios MB, Shan JQ, Faderl S, Garcia-Manero G, Ferrajoli A, Wierda W, Kantarjian H (2003) Effects of age on prognosis with imatinib mesylate therapy for patients with Philadelphia chromosome-positive chronic myelogenous leukemia. Cancer 98(6):1105-1113. doi:10.1002/cncr. 11629

7. Rosti G, Iacobucci I, Bassi S, Castagnetti F, Amabile M, Cilloni D, Poerio A, Soverini S, Palandri F, Cambrin GR, Iuliano F, Alimena G, Latagliata R, Testoni N, Pane F, Saglio G, Baccarani M, Martinelli G (2007) Impact of age on the outcome of patients with chronic myeloid leukemia in late chronic phase: results of a phase II study of the GIMEMA CML Working Party. Haematol 92(1):101-105. doi: 10.3324/haematol.10239

8. Gugliotta G, Castagnetti F, Palandri F, Breccia M, Intermesoli T, Capucci A, Martino B, Pregno P, Rupoli S, Ferrero D, Gherlinzoni F, Montefusco E, Bocchia M, Tiribelli M, Pierri I, Grifoni F, Marzocchi G, Amabile M, Testoni N, Martinelli G, Alimena G, Pane F, Saglio G, Baccarani M, Rosti G (2011) Frontline imatinib treatment of chronic myeloid leukemia: no impact of age on outcome, a survey by the GIMEMA CML Working Party. Blood 117(21): 5591-5599. doi:10.1182/blood-2010-12-324228

9. Pemmaraju N, Kantarjian H, Shan J, Jabbour E, Quintas-Cardama A, Verstovsek S, Ravandi F, Wierda W, O'Brien S, Cortes J (2012) Analysis of outcomes in adolescents and young adults with chronic myelogenous leukemia treated with upfront tyrosine kinase inhibitor therapy. Haematol Hematol J 97(7):1029-1035. doi:10.3324/ haematol.2011.056721

10. Stock W (2010) Adolescents and young adults with acute lymphoblastic leukemia. ASH Educ Program Book 2010(1):21-29. doi:10.1182/asheducation-2010.1.21

11. Advani AS (2013) Biology and treatment of acute lymphocytic leukemia in adolescents and young adults. ASCO Educ Book 2013: 285-289 
12. Anders CK, Johnson R, Litton J, Phillips M, Bleyer A (2009) Breast cancer before age 40 years. Semin Oncol 36(3):237-249. doi:10. 1053/j.seminoncol.2009.03.001

13. Anders CK, Hsu DS, Broadwater G, Acharya CR, Foekens JA, Zhang Y, Wang Y, Marcom PK, Marks JR, Febbo PG, Nevins JR, Potti A, Blackwell KL (2008) Young age at diagnosis correlates with worse prognosis and defines a subset of breast cancers with shared patterns of gene expression. J Clin Oncol 26(20):3324-3330. doi:10. $1200 /$ jco.2007.14.2471

14. Datta RV, LaQuaglia MP, Paty PB (2000) Genetic and phenotypic correlates of colorectal cancer in young patients. New Eng J Med 342(2):137-138. doi:10.1056/NEJM200001133420216

15. Prakash S, Sarran L, Socci N, DeMatteo RP, Eisenstat J, Greco AM, Maki RG, Wexler LH, LaQuaglia MP, Besmer P, Antonescu CR (2005) Gastrointestinal stromal tumors in children and young adults - a clinicopathologic, molecular, and genomic study of 15 cases and review of the literature. J Pediatr Hematol Oncol 27(4): 179-187. doi:10.1097/01.mph.0000157790.81329.47

16. Bleyer A, Barr R, Hayes-Lattin B, Thomas D, Ellis C, Anderson B (2008) The distinctive biology of cancer in adolescents and young adults. Nat Rev Cancer 8(4):288-298. doi:10.1038/nrc2349

17. Hehlmann R, Lauseker M, Jung-Munkwitz S, Leitner A, Mueller MC, Pletsch N, Proetel U, Haferlach C, Schlegelberger B, Balleisen L, Haenel M, Pfirrmann M, Krause SW, Nerl C, Pralle H, Gratwohl A, Hossfeld DK, Hasford J, Hochhaus A, Saussele S (2011) Tolerability-adapted imatinib $800 \mathrm{mg} / \mathrm{d}$ versus $400 \mathrm{mg} / \mathrm{d}$ versus 400 $\mathrm{mg} / \mathrm{d}$ plus interferon-alpha in newly diagnosed chronic myeloid leukemia. J Clin Oncol 29(12):1634-1642. doi:10.1200/jco.2010. 32.0598

18. Bleyer WA (2002) Cancer in older adolescents and young adults: epidemiology, diagnosis, treatment, survival, and importance of clinical trials. Med Pediatr Oncol 38(1):1-10. doi:10.1002/mpo.1257

19. Wein S, Pery S, Zer A (2010) Role of palliative care in adolescent and young adult oncology. J Clin Oncol 28(32):4819-4824. doi:10.1200/ jco.2009.22.4543

20. Ferrari A, Thomas D, Franklin ARK, Hayes-Lattin BM, Mascarin M, van der Graaf W, Albritton KH (2010) Starting an adolescent and young adult program: some success stories and some obstacles to overcome. J Clin Oncol 28(32):4850-4857. doi:10.1200/jco.2009. 23.8097

21. Tonorezos ES, Oeffinger KC (2011) Research challenges in adolescent and young adult cancer survivor research. Cancer 117(10):2295-2300. doi:10.1002/cncr.26058

22. Latagliata R, Breccia M, Carmosino I et al (2005) Elderly patients with $\mathrm{Ph}+$ chronic myelogenous leukemia (CML): results of imatinib mesylate treatment. Leukemia Research 29(3):287-291. doi:doi:dx. doi.org/10.1016/j.leukres.2004.08.002

23. Fabarius A, Leitner A, Hochhaus A, Müller MC, Hanfstein B, Haferlach C, Gohring G, Schlegelberger B, Jotterand M, Reiter A, Jung-Munkwitz S, Proetel U, Schwaab J, Hofmann WK, Schubert J, Einsele H, Ho AD, Falge C, Kanz L, Neubauer A, Kneba M, Stegelmann F, Pfreundschuh M, Waller CF, Spiekermann K, Baerlocher GM, Lauseker M, Pfirrmann M, Hasford J, Saussele S, Hehlmann R (2011) Impact of additional cytogenetic aberrations at diagnosis on prognosis of CML: long-term observation of 1151 patients from the randomized CML Study IV. Blood 118(26):6760 6768. doi:10.1182/blood-2011-08-373902

24. Hughes T, Deininger M, Hochhaus A, Branford S, Radich J, Kaeda J, Baccarani M, Cortes J, Cross NC, Druker BJ, Gabert J, Grimwade D, Hehlmann R, Kamel-Reid S, Lipton JH, Longtine J, Martinelli G, Saglio G, Soverini S, Stock W, Goldman JM (2006) Monitoring CML patients responding to treatment with tyrosine kinase inhibitors: review and recommendations for harmonizing current methodology for detecting BCR-ABL transcripts and kinase domain mutations and for expressing results. Blood 108(1):28-37. doi:2006-01-0092 [pii] 10.1182/blood-2006-01-0092
25. Emig M, Saussele S, Wittor H, Weisser A, Reiter A, Willer A, Berger U, Hehlmann R, Cross NCP, Hochhaus A (1999) Accurate and rapid analysis of residual disease in patients with CML using specific fluorescent hybridization probes for real time quantitative RT-PCR. Leuk 13(11):1825-1832. doi:10.1038/sj.leu.2401566

26. Cross NC (2009) Standardisation of molecular monitoring for chronic myeloid leukaemia. Best Pract Res Clin Haematol 22(3): 355-365

27. Muller MC, Cross NCP, Erben P, Schenk T, Hanfstein B, Ernst T, Hehlmann R, Branford S, Saglio G, Hochhaus A (2009) Harmonization of molecular monitoring of CML therapy in Europe. Leuk 23(11):1957-1963. doi:10.1038/leu.2009.168

28. Baccarani M, Cortes J, Pane F, Niederwieser D, Saglio G, Apperley J, Cervantes F, Deininger M, Gratwohl A, Guilhot F, Hochhaus A, Horowitz M, Hughes T, Kantarjian H, Larson R, Radich J, Simonsson B, Silver RT, Goldman J, Hehlmann R (2009) Chronic myeloid leukemia: an update of concepts and management recommendations of European LeukemiaNet. J Clin Oncol 27(35): 6041-6051. doi:10.1200JCO.2009.25.0779

29. Cross NCP, White HE, Müller MC, Saglio G, Hochhaus A (2012) Standardized definitions of molecular response in chronic myeloid leukemia. Leuk 26(10):2172-2175

30. Baccarani M, Saglio G, Goldman J, Hochhaus A, Simonsson B, Appelbaum F, Apperley J, Cervantes F, Cortes J, Deininger M, Gratwohl A, Guilhot F, Horowitz M, Hughes T, Kantarjian H, Larson R, Niederwieser D, Silver R, Hehlmann R (2006) Evolving concepts in the management of chronic myeloid leukemia: recommendations from an expert panel on behalf of the European LeukemiaNet. Blood 108(6): 1809-1820. doi:10.1182/blood-2006-02-005686

31. Pfirmann M, Hochhaus A, Lauseker M, Sausele S, Hehlmann R, Hasford J (2011) Recommendations to meet statistical challenges arising from endpoints beyond overall survival in clinical trials on chronic myeloid leukemia. Leukemia 25(9):1433-1438

32. Gooley T, Leisenring W, Crowley J, Storer BE (1999) Estimation of failure probabilities in the presence of competiting risks:new representations of old estimators. Stat Med 18(6):695-706

33. Gray RJ (1988) A class of k-sample tests for comparing the cumulative incidence of a competing risk. Ann Stat 16(3):11411154. doi:10.1214/aos/1176350951

34. Statistical Yearbook for the Federal Republic of Germany including "International tables" (2011). Federal Statistical Office, Wiesbaden

35. Bleyer A OLM, Barr R, Ries LAG (eds): Cancer Epidemiology in Older Adolescents and Young Adults 15 to 29 Years of Age, Including SEER Incidence and Survival:1975-2000. National Cancer Institute, NIH Pub. No. 06-5767. Bethesda, MD 2006. http://seer.cancer.gov/publications/aya/. Accessed 10 March 2012.

36. Adler R, Viehmann S, Kuhlisch E, Martiniak Y, Röttgers S, Harbott J, Suttorp M (2009) Correlation of BCR/ABL transcript variants with patients characteristics in childhood chronic myeloid leukemia. Eur J Haematol 82(2):112-118

37. Millot F, Suttorp M, Guilhot J, Sedlacek P, De Bont ES, Li CK, Kalwak K, Lausen B, Srdjana C, Dresse M-F, Biondi A, Baruchel A (2012) The International Registry for Chronic Myeloid Leukemia (CML) in Children and Adolescents (I-CML-Ped-Study): objectives and preliminary results. ASH Annu Meeting Abstracts 120(21):3741

38. Millot F, Traore P, Guilhot J, Nelken B, Leblanc T, Leverger G, Plantaz D, Bertrand Y, Bordigoni P, Guilhot F (2005) Clinical and biological features at diagnosis in 40 children with chronic myeloid leukemia. Pediatr 116(1):140-143. doi:10.1542/peds.2004-2473

39. Hanfstein B, Müller MC, Hehlmann R, Erben P, Lauseker M, Fabarius A, Schnittger S, Haferlach C, Goehring G, Proetel U, Kolb HJ, Krause SW, Hofmann WK, Schubert J, Einsele H, Dengler J, Haenel M, Falge C, Kanz L, Neubauer A, Kneba M, Stegelmann F, Pfreundschuh M, Waller CF, Branford S, Hughes TP, Spiekermann K, Baerlocher GM, Pfirmann M, Hasford J, Saussele S, Hochhaus A, Sakk GCMLSG (2012) Early molecular and 
cytogenetic response is predictive for long-term progression-free and overall survival in chronic myeloid leukemia (CML). Leuk 26(9): 2096-2102. doi:10.1038/leu.2012.85

40. Marin D, Ibrahim AR, Lucas C, Gerrard G, Wang L, Szydlo RM, Clark RE, Apperley JF, Milojkovic D, Bua M, Pavlu J, Paliompeis C, Reid A, Rezvani K, Goldman JM, Foroni L (2012) Assessment of BCR-ABL1 transcript levels at 3 months is the only requirement for predicting outcome for patients with chronic myeloid leukemia treated with tyrosine kinase inhibitors. J Clin Oncol 30(3):232-238. doi:10.1200/jco.2011.38.6565

41. Baccarani M, Deininger MW, Rosti G, Hochhaus A, Soverini S, Apperley JF, Cervantes F, Clark RE, Cortes JE, Guilhot F, HjorthHansen H, Hughes TP, Kantarjian HM, Kim DW, Larson RA, Lipton JH, Mahon FX, Martinelli G, Mayer J, Muller MC, Niederwieser D, Pane F, Radich JP, Rousselot P, Saglio G, Saussele S, Schiffer C, Silver R, Simonsson B, Steegmann JL, Goldman JM, Hehlmann R (2013) European LeukemiaNet recommendations for the management of chronic myeloid leukemia: 2013. Blood. doi:10. 1182/blood-2013-05-501569

42. Gryfe R, Kim H, Hsieh ETK, Aronson MD, Holowaty EJ, Bull SB, Redston M, Gallinger S (2000) Tumor microsatellite instability and clinical outcome in young patients with colorectal cancer. N Engl J Med 342(2):69-77. doi:10.1056/nejm200001133420201

43. Vriens M, Moses W, Weng J et al (2011) Clinical and molecular features of papillary thyroid cancer in adolescents and young adults. Cancer 117(2):259-267

44. Harrison CJ (2009) Cytogenetics of paediatric and adolescent acute lymphoblastic leukaemia. Br J Haematol 144(2):147-156. doi:10. 1111/j.1365-2141.2008.07417.x
45. Belloc F, Moreau-Gaudry F, Uhalde M, Cazalis L, Jeanneteau M, Lacombe F, Praloran V, Mahon F-X (2007) Imatinib and Nilotinib induce apoptosis of chronic myeloid leukemia cells through a Bimdependant pathway modulated by cytokines. Cancer Biology \& Therapy 6(6):912-919

46. Zhang B, Li M, McDonald T, Holyoake TL, Moon RT, Campana D, Shultz L, Bhatia R (2013) Microenvironmental protection of CML stem and progenitor cells from tyrosine kinase inhibitors through Ncadherin and Wnt- $\beta$-catenin signaling. Blood 121(10):1824-1838. doi:10.1182/blood-2012-02-412890

47. Mustjoki S, Richter J, Barbany G, Ehrencrona H, Fioretos T, GeddeDahl T, Gjertsen BT, Hovland R, Hernesniemi S, Josefsen D, Koskenvesa P, Dybedal I, Markevarn B, Olofsson T, OlssonStromberg U, Rapakko K, Thunberg S, Stenke L, Simonsson B, Porkka K, Hjorth-Hansen H (2013) Impact of malignant stem cell burden on therapy outcome in newly diagnosed chronic myeloid leukemia patients. Leuk 27(7):1520-1526. doi:10.1038/leu.2013.19

48. Druker BJ, Guilhot F, O'Brien SG, Gathmann I, Kantarjian H, Gattermann N, Deininger MW, Silver RT, Goldman JM, Stone RM, Cervantes F, Hochhaus A, Powell BL, Gabrilove JL, Rousselot P, Reiffers J, Cornelissen JJ, Hughes T, Agis H, Fischer T, Verhoef G, Shepherd J, Saglio G, Gratwohl A, Nielsen JL, Radich JP, Simonsson B, Taylor K, Baccarani M, So C, Letvak L, Larson RA (2006) Five-year follow-up of patients receiving imatinib for chronic myeloid leukemia. N Engl J Med 355(23):2408-2417. doi:10.1056/NEJMoa062867

49. Aben KKVGC, Van Gils NA, Van der Graaf WT, Zielhuis GA (2012) Cancer in adolescents and young adults (15-29 years): a populationbased study in the Netherlands 1989-2009. Acta Oncologica 51(7): 922-933. doi:10.3109/0284186X.2012.705891 